\title{
The Coxford Lecture Honour, Oaths, and the Rule of Law
}

Paul Horwitz

\section{Introduction}

"The rule of law" is a popular, protean, and unclear phrase. Since the repatriation of the Constitution and enactment of the Canadian Charter of Rights and Freedoms in 1982 alone, it has been used by the Supreme Court of Canada 399 times, 213 of them in this century. ${ }^{1}$

Usually, its usage is an example of what Richard Posner has called "Law Day rhetoric:"2 imprecise, unhelpful, banal. In a case involving "legal and constitutional questions of the utmost subtlety and complexity," for example, the Supreme Court of Canada examined the rule-of-law consequences of invalidating unilingual legislation passed by Manitoba. ${ }^{3}$ Canvassing sources from Locke to Raz, the Court concluded that the rule of law requires the presence and not the utter absence of positive law-order, not anarchy. One can agree with this statement while finding it underwhelming.

Occasionally, judges or legal scholars try to flesh out the meaning of the "rule of law," focusing on qualities like "[g]enerality, promulgation [or publicity], and clarity." Even so, judges acknowledge that the phrase is often invoked unhelpfully. ${ }^{5}$

I am grateful to the University of Western Ontario School of Law for the opportunity to deliver the Coxford Lecture on March 10, 2016, and to Stephen Coxford, whose generosity supports this lecture series. I am especially grateful to Professor Andrew Botterell, who first invited me to give that lecture and then exhibited saintly patience waiting for the written product. I also thank the students in my reading group on oaths, honour, and the United States Constitution at Harvard Law School in the spring of 2016.

1. These numbers come from a May 2019 search of the Westlaw "Supreme Court of Canada and Privy Council Cases and Decisions" database for the phrase "rule of law." I have not controlled for occasional irrelevant usages. E.g., Benhaim v St-Germain, 2016 SCC 48, para 4 ("[N]o rule of law requires the trier of fact to draw an adverse inference of causation where the defendant's negligence has undermined the plaintiff's ability to prove causation, even where there is some evidence of causation.")

2. Richard A Posner, How Judges Think (Harvard University Press, 2008) at 1; Richard J Fallon, Jr, “"The Rule of Law' as a Concept in Constitutional Discourse" (1997) 97 Colum L Rev 1 at 2 ("[M]any invocations of the Rule of Law are smug or hortatory.") [Fallon].

3. Reference re Language Rights Under s 23 of Manitoba Act 1870 and s 133 of Constitution Act 1867, [1985] 1 SCR 721 at para 1.

4. $R v$ Ferguson, [2008] 1 SCR 96 at para 68 (citing Lon L Fuller, The Morality of Law, 2nd ed (Yale University Press, 1969) at 33-39). For scholarly examples, see, e.g., Peter W Hogg \& Cara F Zwibel, "The Rule of Law in the Supreme Court of Canada" (2005) 55 UTLJ 715; Ian Shapiro, ed, The Rule of Law: Nomos XXXVI (NYU Press, 1995).

5. Singh v Canada (Attorney General), [2000] 3 FC 185 at para 33 ("Advocates tend to read into the principle of the rule of law anything which supports their particular view of what the law should be."). 
One frequently identified feature of the rule of law is impersonality. The rule of law is frequently contrasted with the rule of men or women. ${ }^{6} \mathrm{~A}$ "central feature of liberalism," writes William Powers, "is its commitment to a social order governed by moral and legal rules that are general, impartial, and impersonal-that is, its commitment to the rule of law." "We often acknowledge that judges "bring with them to judging all their life experiences," and value the varied perspectives that judges, especially those from under-represented communities, bring to their role. ${ }^{8}$ But we still expect their decisions to turn on the law, not their identity. ${ }^{9}$

It may thus seem perverse to insist on the importance of honour to the rule of law. Honour is personal, comprising qualities like "high and principled ambition, courage, pride, and the desires for self-respect and public esteem." dignity, a "fixed status that attaches to all persons," it involves personal motives and individual distinction. ${ }^{11}$

The ostensible perversity is compounded by two other things. First, many have argued that honour is obsolete in liberal democratic societies. ${ }^{12}$ Charles Taylor has written of "the evolution of Western moral consciousness from an external ethic of honor to an internal ethic of dignity." 13 This shift is "generally seen as a leap forward in our moral development." 14 Second, another key element of this articlethe oath-is also viewed as a relic at best. Insisting on the importance of both honour and oaths, especially in the context of the rule of law, may seem quixotic.

It is not. I argue that honour and the oath are closely connected. Neither are out of place in liberal democratic societies, especially where judges and other officials are concerned, and both are vital to the rule of law. Neither dignity nor impersonality can do the work necessary to maintain such a system. Honour, combined with and instantiated by the oath, helps supply and channel the energies and duties of officials in a healthy liberal democratic society. Liberal constitutionalism, far from making honour obsolete, requires honour and the oath, as both a wellspring of energy and agency and a constraint on that agency.

6. E.g., Fallon, supra note 2 at 2-3; Marbury $v$ Madison, 5 US (1 Cranch) 137 (1803) at 163 ("The government of the United States has been emphatically termed a government of laws, and not of men") [Marbury].

7. William Powers, Jr, "Liberalism, Romanticism, and the Rule of Law" (1991) 69 Tex L Rev 977 at 983 [Powers].

8. Bizon v Bizon, 2014 ABCA 174 at para 36.

9. E.g., $R \vee S(R D), 1997$ SCR 484.

10. Sharon R Krause, Liberalism With Honor (Harvard University Press, 2002) at xii [Krause].

11. Ibid at 13 . For the rise of dignity as a legal value, see, e.g., Doron Shultziner \& Guy E Carmi, "Human Dignity in National Constitutions: Functions, Promises and Dangers" (2014) 62 Am J Comp L 461. For book-length treatments, see, e.g., Jeremy Waldron, Dignity, Rank, and Rights, edited by Meir Dan-Cohen (Oxford University Press, 2012) [Waldron]; Michael Rosen, Dignity: Its History and Meaning (Harvard University Press, 2012); George Kateb, Human Dignity (Harvard University Press, 2011).

12. Peter Berger, "On the Obsolescence of the Concept of Honour" in Michael J Sandel, ed, Liberalism and its Critics (New York University Press, 1984) at 149 [Berger].

13. Nathan B Oman, "The Honor of Private Law" (2011) 80 Fordham L Rev 31 at 51 (discussing Charles Taylor, Sources of the Self: The Making of the Modern Identity (Harvard University Press, 1989) at 204-10) [Oman].

14. Peter Olsthoorn, Honor in Political and Moral Philosophy (State University of New York Press, 2015) at 3 [Olsthoorn]. 
We may need to remake honour to render it fitting for modern use, but we certainly cannot dispense with it.

I begin by defining honour, with an emphasis on a modern, democratic form of honour. I will then discuss the oath and its connection to honour, particularly through the concept of office. Finally, I discuss the connection between honour, office, and oath, and argue for the value of this "troika" to the rule of law. I address some possible objections to honour and the oath in contemporary law and society. For reasons of scope and space, however, the objections and responses canvassed here are far from comprehensive.

\section{Honour Defined, Distinguished, and Defended}

Honour is experiencing a modern scholarly and popular renaissance. ${ }^{15}$ To be sure, many argue that dignity has superseded honour in our social imaginary. ${ }^{16}$ Nevertheless, in recent years, an increasing number of scholars have treated honour as a subject worthy of renewed attention. ${ }^{17}$

Defining honour poses problems of clarity and specificity. "The primary methodological difficulty within the study of honor," writes Robert Oprisko, "is that the word means many things .... We use multiple concepts interchangeably when speaking about honor, disregarding conceptual differences."18 Still, we should not overstate the difficulty of arriving at a working definition. "Honor pervades human history and contemporary cultures, not least our own." 19 We still use it routinely in informal conversation today, and understand each other, more or less, when we do. Any term that has been the subject of sustained analysis by such writers as Aristotle, Cicero, Hobbes, Montesquieu, and Tocqueville can hardly be said to be beyond useful understanding.

The anthropologist Julian Pitt-Rivers supplied a highly influential modern definition, stressing honour's dual nature: "Honour is the value of a person in his own eyes, but also in the eyes of his society. It is his estimation of his own worth, his claim to pride, but it is also the acknowledgement of that claim,

15. See Olsthoorn, ibid at 4. An excellent recent contribution to the literature is Laurie M Johnson \& Dan Demetriou, eds, Honor in the Modern World: Interdisciplinary Perspectives (Lexington Books, 2016) [Johnson \& Demetriou].

16. This view is strongly associated with Charles Taylor, among others. E.g., Charles Taylor, "The Politics of Recognition" in Charles Taylor, ed, Philosophical Arguments (Harvard University Press, 1995) at 225.

17. See Robert L Oprisko, Honor: A Phenomenology (Routledge, 2012) at 3 [Oprisko]. I rely heavily in this article on the following sources, listed alphabetically by author: Kwame Anthony Appiah, The Honor Code: How Moral Revolutions Happen (WW Norton, 2011) [Appiah]; Anthony Cunningham, Modern Honor: A Philosophical Defense (Routledge, 2013); Krause, supra note 10; Olsthoorn, supra note 14; William Lad Sessions, Honor For Us: A Philosophical Analysis, Interpretation and Defense (Bloomsbury, 2010) [Sessions]; Waldron, supra note 11; Alexander Welsh, What is Honor? A Question of Moral Imperatives (Yale University Press, 2008).

18. Oprisko, ibid at 4.

19. Sessions, supra note 17 at 1 . 
his excellence recognized by society, his right to pride." 20 These internal and external aspects of honour are intimately connected. "Indeed, it has seemed proper to see honor precisely as a single thing with different 'aspects.",21

Internal honour is a form of "self-reflective evaluation" 22 on the part of "self-regarding and self-aware agents." 23 The focus on honour's internal aspects is "distinctively modern, ... something less hierarchical, and a little more internalized" than ancient conceptions. ${ }^{24}$ Although it is closely connected to external honour, internal honour focuses on one's self-conception, not one's actual reputation. Thus, cadets at West Point are "expected to live by [their honour code] because they have internalized it, not because they are concerned about what others might think about them when they breach it." 25

Anyone in a position of public trust, including lawyers and judges, should understand this readily. They may care about outward reputation, but they regularly act ethically even when they could violate their obligations without being found out. It is not the fear of discovery alone that motivates them to act ethically. It is a sense of self, a desire to embody and live up to a set of norms and values that have come to define them in their own eyes. ${ }^{26}$ Internal honour is thus often treated as "a personal quality or virtue" closely tied to integrity. ${ }^{27}$

Without doing full justice to the relationship between internal honour and terms such as integrity, conscience, virtue, or rule-following, we can say that internal honour entails both more and less than those qualities. ${ }^{28}$ Conscience is individual, and need not rely on community-based requirements for proper behaviour. Similarly, virtue involves "study[ing] how the best person meets a variety of particular situations, rather than follow[ing] a fixed set of general prescriptions." 29 Some forms of virtue, moreover, focus on duties to others. Internal honour involves a duty to oneself and to one's self-respect. ${ }^{30}$ It is more rulebound and categorical than a situation-dependent sense of virtue, and hence less demanding in some ways. Demonstrating its connection to external honour and to one's "honor group," 31 internal honour relies not on a priori reflection on right conduct, but on an existing code of conduct belonging to and defining a particular community.

At the same time, "Honor is more than a virtue[,] because it combines a quality of character, a particular right desire, with general rules of conduct, and

20. Julian Pitt-Rivers, "Honour and Social Status" in JG Péristiany, ed, Honour and Shame: The Values of Mediterranean Society (Weidenfeld \& Nicolson, 1994) 19 at 22 [Pitt-Rivers].

21. Frank Henderson Stewart, Honor (University of Chicago Press, 1994) at 12 [Stewart].

22. Oprisko, supra note 17 at 7.

23. Krause, supra note 10 at 55 .

24. Olsthoorn, supra note 14 at 34 .

25. Ibid at 11 .

26. Ibid.

27. Ibid.

28. Olsthoorn, supra note 14 at 15 ; Krause, supra note 10 at ch 1 .

29. Krause, ibid at 4.

30. Ibid at 5 .

31. Olsthoorn, supra note 14 at 13. 
consequently cannot be collapsed simply into the category of virtue." 32 And it is more than simply following rules, which people can do without internalizing them as a source of self-worth. It involves being driven to live up to the "self as I want to be." 33

The focus of external honour is on how the honourable individual is viewed by others: "our value in the eyes of society." 34 It embraces things like "esteem, glory, or reputation." "35 Beyond general public recognition, external honour also prizes the esteem of one's peers within an honour group, or what Kwame Anthony Appiah labels “"peer honor,' which governs relations among equals" within an honour group. ${ }^{36}$

External honour can take several forms. One especially important distinction is between vertical and horizontal honour. Vertical honour is "the right to special respect enjoyed by those who are superior, whether by virtue of their abilities, their rank, their services to the community, their sex, their kin relationship, their office, or anything else." ${ }^{\prime 37}$ Even in ostensibly egalitarian democratic societies, we may accord special respect to doctors and other professionals, or to judges and other office-holders, regardless of their own individual excellence. But much honour that is significant to the honouree is horizontal, in that it is accorded by one's peers. Horizontal honour offers "a source of solidarity among social equals." 38 One hungers to be counted as worthy of recognition by an honour group composed of one's peers. A judge may expect to be treated with respect by virtue of her office, but being counted as excellent by one's fellow judges is a more powerful source of self-worth and a stronger incentive for right conduct as a judge.

Internal and external honour are closely linked. Recall Pitt-Rivers' definition: honour "is the value of a person in his own eyes, but also in the eyes of his society." " 39 Two points demand notice here. First, the value of a person "in the eyes of his society" has an objective aspect. The concern is with being properly seen as honourable. We are "anxious about how others would value us if they were fully informed." 40 Our sense of honour ultimately depends on "the imaginary view of all-knowing others." 41 Adam Smith noted that "man is not only endowed "with a desire of being approved of, but with a desire of being what ought to be approved of." 42 Second, external and internal honour are connected through the process of

32. Krause, supra note 10 at 5.

33. Anthony Giddens, Modernity and Self-Identity: Self and Society in the Late Modern Age (Stanford University Press, 1991) at 68 (quoted in Olsthoorn, supra note 14 at 9).

34. Olsthoorn, supra note 14 at 8.

35. Alexis de Tocqueville, Democracy in America, vol 2, ed and translated by Philips Bradley (AA Knopf, 1980) at 230 (quoted in Krause, supra note 10 at 71) [Tocqueville].

36. Appiah, supra note 17 at 14 .

37. Stewart, supra note 21 at 59.

38. Berger, supra note 12 at 151 .

39. Pitt-Rivers, supra note 20 at 22.

40. Olsthoorn, supra note 14 at 8 [emphasis in original].

41. Ibid.

42. Ibid at 8 (quoting Adam Smith, The Theory of Moral Sentiments (Oxford Clarendon Press, 1976) at III.2.7) [emphasis added]. 
internalization. Honour includes public recognition, but it also involves "a quality of character, the ambitious desire to live up to one's code and to be publicly recognized for doing so."43

Although the idea of an internalized sense of honour has been called "distinctively modern," 44 that is not entirely true. One of the most influential ancient champions of honour, Cicero, distinguished between "true" and "false" glory. True glory consists of

the agreed approval of good men, the unbiased verdict of judges deciding honestly the question of pre-eminent merit; it gives back to virtue the echo of her voice. ${ }^{45}$

For Cicero, "wish[ing] for glory as a reward for his achievements" was a fine thing. ${ }^{46}$ However, that glory must not be based on "[m]ere 'pretence' and 'empty show." Ultimately, to achieve earned glory one must "strive to be what you wish to be thought to be."47

Honour can thus be thought of as a self-conception that is closely tied to the conception that others hold of one. It does not rest on one's actual reputation alone. Rather, it involves a desire to deserve to be thought well of by one's peers: to live up to that set of virtues or excellences for which the reward is fame, glory, or a good reputation. Although we have already distinguished virtue and honour, the fact that "undeserved praise [should give] us little pleasure shows that the two are closely connected." $" 48$ We want our names to resound deservedly among our peers and, perhaps, beyond. In wanting to embody the qualities that deserve such recognition, we internalize them and seek to live up to them in our actions.

Honour thus lies between virtue-based and code-based behavior, serving as "both a quality of character and rule-governed [conduct]." 49 Similarly, it stands between the purely internal sense of civic virtue that consists of a sense of duty toward others, and the mere love of fame. It rests on a desire for earned fame, and that desire will lead one to act honourably whether one is recognized for it or not. ${ }^{50}$

So defined, honour may sound attractive enough, but a longstanding view holds that it is both unattractive and obsolete. A champion of honour can expect to hear, via Shakespeare's Falstaff, that it is a "word," a "mere scutcheon." ${ }^{\text {" One may }}$ encounter Peter Berger's description of honour as an "ideological leftover[ ] in the consciousness of obsolete classes." 52 One will certainly hear a litany of

43. Krause, supra note 10 at 2 .

44. Olsthoorn, supra note 14 at 34 .

45. Cicero, Tusculanae Disputationes at III.3-4, quoted in Olsthoorn, supra note 14 at 24.

46. Cicero, De Officiis I.91, quoted ibid at 24.

47. Cicero, De Officiis II.43, quoted ibid at 25.

48. Ibid at 25 .

49. Krause, supra note 10 at 4.

50. Cicero, De Officiis I.65, quoted in Olsthoorn, supra note 14 at 24 ("[T]rue ... greatness of spirit regards the moral goodness to which nature aspires most as consisting in deeds, not fame, and prefers to be first in reality rather than in name.").

51. William Shakespeare, Henry IV, Part 1, act V, sc 1, lines 125-41 (Bertrand Evans ed, 1963).

52. Berger, supra note 12 at 149. 
"honor's 'dark side:",53 its connection to slavery, sexism, colonialism, dueling, honour killings, and other evils. Although honour has a more lasting and positive influence than this picture suggests, and has acquired an increasing number of advocates, it remains true that "many contemporary people dislike talk of 'honor."' 54

There are answers to the standard criticisms. ${ }^{55}$ None of these criticisms precludes a modern form of liberal honour, but one broader criticism, associated with Charles Taylor and Peter Berger, is worth addressing here. This argument is that the "pre-modern" culture of honour has been superseded by " $[t]$ he modern discovery of dignity," which "took place precisely amid the wrecking of debunked conceptions of honour." 56 Honour is limited to particular groups and closely associated with aristocratic status; dignity "pertains to the individual as such, to the individual regardless of his position in society." 57 Modern conceptions of humanity and human rights reject the differentiation among individuals and groups prevalent in honour-based societies and hold that "[a]11 human beings are born free and equal in dignity and rights." This dignitarian perspective is widely recognized in domestic constitutional law ${ }^{59}$ and international human rights law. ${ }^{60}$ Unlike honour, which is closely tied to institutions, in a dignitarian system "the individual can only discover his true identity by emancipating himself from his socially imposed roles." ${ }^{61}$ Modern men and women, in short, have "los[t] honor at the expense of dignity." 62

This line of criticism is likely to appeal to many modern intellectuals, academics, and professionals, including lawyers and judges. ${ }^{63}$ And of course there is great value in the dignitarian position, in law and elsewhere. Still, for two key reasons, this line of criticism is at least overstated. The first concerns the specific context of this article. It focuses not on the general status of dignity or honour,

53. Sessions, supra note 17 at 4.

54. Ibid at 19. Typical criticisms are laid out in Sessions, ibid at 4-6, and include the following: 1) Honour is shallow and encourages conformity and hypocrisy; 2) honour depends on an antiquated culture of hierarchy; 3 ) honour functions better with small groups than under the conditions of mass society; 4) honour fails to recognize the multiplicity of people's identities and attachments; 5) honour is inegalitarian and elitist; 6) honour is closely linked to patriarchy; 7) honour is complicit in violence such as dueling and honour killings.

55. E.g., ibid at 155-71.

56. Ibid at 153 .

57. Ibid.

58. Universal Declaration of Human Rights, GA Res 217 (III) A, UN Doc A/RES/217(III), at art I (Dec 10 1948).

59. E.g., Obergefell v Hodges, $135 \mathrm{~S} \mathrm{Ct} 2584$ (2015) at 2607 (recognizing a constitutional right of same-sex marriage and stressing "equal dignity in the eyes of the law").

60. E.g., Louis Henkin, Gerald L Neuman, Diane F Orentlicher \& David W Leebron, Human Rights (Foundation Press, 1999) at 80 (calling human dignity the "ur-principle" of human rights law).

61. Berger, supra note 12 at 154 .

62. Ibid at 158 .

63. E.g., ibid at 157 . But see ibid at 158 (acknowledging the possibility that "a rediscovery of honor in the future development of modern society is both empirically plausible and morally desirable"). Jeremy Waldron has argued for a conception of dignity as a legal principle that consists of 'universalized high social rank, which amounts to a reversal of [the] trend [of treating honour as having been superseded by dignity] by tying dignity back to honor rather than to [equal intrinsic] worth." Meir Dan-Cohen, Introduction in Waldron, supra note 11. 
but on the specific value of honour for office-holders. One can agree with this point without abandoning one's belief in human dignity, or the belief in dignity as an important legal value, especially in the area of individual rights. The second reason builds on that point. Even — or especially_for judges who see their job as both "impersonal" and respectful of equal dignity, honour can be a vital source of motivation and agency. Perhaps ironically, a sense of honour may help judges to uphold the rule of law and advance equal human dignity.

Allow me to expand on these two points. First, this article's narrow focus on the question of how and why judges perform their office renders irrelevant many common criticisms of honour. Take, for example, the criticism that "modern mass societies" are "too vast and impersonal to exemplify honor." 64 Judges are not a vast and impersonal group. The judiciary is already a small, narrowly defined peer group, in which collegial esteem is an important motivating factor. ${ }^{65}$

More broadly, judges are not unrooted or isolated from institutions. "Honor is grounded in particular social and political identities that yield specific standpoints and obligations." 66 Tocqueville worried that "honor 'is necessarily less powerful' because it is less clearly defined" in "modern democratic regimes "where all the citizens are mobile, where society, being modified every day, changes its opinions with changing needs." 67 But judges $d o$ belong to a relatively stable institution, in which "individuals identify themselves with the escutcheons of their institutional roles." ${ }^{68}$ Unsurprisingly, law and other professions have long been identified as areas in which honour continues to be a relevant force. ${ }^{69}$ Honour, in short, remains a viable possibility for judges.

But viable for what? How does honour, which is often taken to be a mere precursor to dignity or even its opposite, help judges to do a better job of administering a set of legal and social values that are themselves focused not on honour but on the equal dignity of all persons?

The answers lie in agency, motivation, constraint, and discretion. Recall the description of liberalism's "commitment to a social order governed by moral and legal rules that are general, impartial, and impersonal - that is, its commitment to the rule of law."70 Our focus here is on the word "commitment." Even if we know what judges are supposed to do, what can we say about how and why they do itabout the source of their commitment, including the energy and motivation needed to create and sustain it?

64. Sessions, supra note 17 at 5.

65. E.g., Frederick Schauer, "Incentives, Reputation, and the Inglorious Determinants of Judicial Behavior" (1999) 68 U Cinn L Rev 615 at 618, 629 (arguing for the importance of reputation in motivating judges, with a focus on peer groups).

66. Krause, supra note 10 at 57.

67. Ibid at 73 (quoting Tocqueville, supra note 35 at 246).

68. Berger, supra note 12 at 158 (describing conditions under which "a rediscovery of honour" might be plausible and desirable).

69. E.g., Sessions, supra note 17 at ch 10 (describing the value and continuing relevance of "professional honor"); Appiah, supra note 17 at 190-95; W Bradley Wendel, "Regulation of Lawyers Without the Code, the Rules, or the Restatement: Or, What do Honor and Shame Have to do with Civil Discovery Practice?" (2003) 71 Fordham L Rev 1567.

70. Powers, supra note 7 at 983. 
This is the subject of Sharon Krause's invaluable book Liberalism With Honor. ${ }^{71}$ Krause asks how we can "generate[ ] the possibility of resistance to majorities that go bad," particularly in light of the fear that individual rights may prove mere "parchment barriers" in the face of tyranny of the majority. ${ }^{72}$ As Richard Parker puts it, what "spring of motion" or "motivation" can sustain the legal and political action needed to protect our "democratic constitutional order?"

Much of the time, we simply do not ask this question. We identify the nature of the good, or the rights that deserve protection in a liberal democratic society, and ask whether judges' decisions are consistent with those conclusions. But this does not tell us how to motivate officials to act on behalf of these values and rights. We are simply "left to speculate" about what provides this motivation. ${ }^{74}$ Perhaps, like Dworkin, we simply imagine that judges are "Hercules" figures, "ideal judge[s] endowed with infinite patience and resourcefulness" and energy. ${ }^{75}$ Naturally, once these Herculean judges catch "a glimpse of the ideal," they will act to pursue it. ${ }^{76}$

That is a rather unconvincing answer. In our world, most judges, like most people, are more like "Herbert": "pedestrian" types who are "less brilliant, less resourceful, less patient," and less energetic than Hercules. ${ }^{77}$ Something must fuel their individual agency: "the capacity for intentional, self-initiated action."78 Without it, there is no wind in the judge's sails, and the ship of justice moves slowly or is becalmed altogether.

Under these conditions, rights and the rule of law are indeed more likely to be mere parchment barriers. At best, individual rights and the rule of law are maintained, but in a desultory or passive manner. A central question for liberal and constitutional states is how to provide the sense of agency that will make the system function fully and energetically. ${ }^{79}$ Liberal theory often lacks "an acknowledgment of liberal democracy's need for heroic qualities of character." 80

A modernized honour helps fill that need. "The particular combination of qualities intrinsic to honor support heroic action: high and principled ambition, courage, pride, and the desires for self-respect and public esteem." 81

71. Krause, supra note 10. Legal scholarship drawing on Krause includes Oman, supra note 13; Wendel, supra note 69; Peter Brandon Bayer, "Sacrifice and Sacred Honor: Why the Constitution is a "Suicide Pact" (2011) 20 Wm \& Mary Bill Rts J 287; and Richard D Parker, "Democratic Honor: Liberal and Populist" (2004) 39 Harv CR-CL L Rev 291 [Parker].

72. Krause, supra note 10 at ix. The term "parchment barriers" comes from James Madison.

73. Parker, supra note 71 at 291.

74. Ibid.

75. Adrian Vermeule \& Ernest A Young, "Hercules, Herbert, and Amar: The Trouble with Intratextualism" (2000) 113 Harv L Rev 730 at 730 [Vermeule \& Young]; Ronald Dworkin, "Hard Cases" (1975) 88 Harv L Rev 1057 (introducing Hercules).

76. Parker, supra note 71 at 295.

77. Vermeule \& Young, supra note 75 at $732,759$.

78. Krause, supra note 10 at 1.

79. Ibid at 9 ("Formal liberties, then, can be effective only where there is a will to use and defend them.").

80. Ibid at 11 .

81. Ibid at 12 . 
Human dignity as such, which by definition is independent of individual qualities of agency, energy, or virtue, is not a strong motivation to act in its defense. The "remainder" left over between honour and dignity is that set of virtues and values "comprising the courage, pride, high and principled ambition, and the rest that constitute honour as a quality of character." 82

The love of honour can move officials (including judges) to act. It "embodies, above all, ... a motivation to action." 83 Insofar as honour is connected to one's "self-image and self-respect," and thus to "an urge to honorable behavior, ... to prove oneself to oneself and to others through action," it provides the springs for energetic action. ${ }^{84}$

As we have seen, a key component of honour as motivation is concern for one's reputation, especially within a particular peer group. It involves not only one's actual reputation, but an internalized desire to be seen as deserving one's good repute by embodying and displaying honour, properly understood. Even pragmatists and Legal Realists, whether judges or others, "need[ ] symbols as well as statistics, heroes in addition to hearings." 85 Judges delight in praising other judges for their inspiring virtues. And they care about their own "reputation, prestige, esteem, and status," 86 particularly within their own peer group.

Because judges want to deserve to be thought of highly by their peers, they emulate and internalize the values that their peer group thinks of as emblematic of the good or great judge. The desire to exemplify these values, and to be acknowledged by their peers as exemplary, adds agency and energy to their work. Given their modern values and vocabulary, they may not think of this desire as involving honour, an honour group, or a form of "natural aristocracy." 87 But that is what it is.

\section{Office and Oath}

Honour thus remains relevant and important in modern society, despite the decline of honour talk in modern Western society and the rise of the language of equal dignity. It is especially relevant for judges and other political officials. Their unique position of duty, accountability, and achievement places them in a context in which something more than dignity is needed as a source of agency, energy, and independence.

Nevertheless, and despite remnants of honour talk—such as referring to judges as "Your Honour" - there is, at first glance, little by way of direct reference to honour as an official component of judging or other forms of office-holding. The language of modern constitutions is mostly democratic and egalitarian.

82. Ibid at 16 .

83. Parker, supra note 71 at 299.

84. Ibid.

85. Sarah Barringer Gordon, "Commentary: The Creation of a Usable Judicial Past: Max Lerner, Class Conflict, and the Propagation of Judicial Titans" (1995) 70 NYU L Rev 622 at 637.

86. Mitu Gulati \& CMA McCauliff, "On Not Making Law" (1998) 61 L \& Contemp Probs 157 at 165.

87. Krause, supra note 10 at xii. 
The United States Constitution, for instance, explicitly forbids the federal government to grant "titles of nobility." 88 Newer constitutions are even more likely to reflect notions of democracy, equality, and dignity rather than anything like honour. ${ }^{89}$

That is far from the whole story, however. At least in the common-law tradition, including its manifestation in constitutional law, two ancient features of the legal and constitutional structure - and of the rule of law more broadly - connect honour to judging, and the personal motivations and agency of individual judges to their role in maintaining the rule of law. ${ }^{90}$ They are more than placeholders or vessels into which the concept of honour can be poured by a willful interpreter. Viewed correctly, they connect the judge and his or her desire for earned reputation to the ostensibly impersonal performance of the judicial task. These closely connected structural devices are office and the oath. Between them, they ensure that honour has a continuing role to play in the rule of law, despite that concept's emphasis on impersonality.

\section{Office and Judicial Office}

As Steve Sheppard writes, "The building blocks of a modern legal system are offices, and the essential purpose of offices is to fulfill tasks of the legal system." 91 Sheppard defines legal officials as "the individuals in whom all of the powers of the state are allocated, divided among many roles." 92 In each case, "the official is both empowered and limited by the law:" subject to "the legal obligations embedded in that particular office by the rules of law" but, within the scope of that office, possessing substantial "discretion to act or not to act.",93

The notion of office in Western law dates back to the development of the concept in ancient Rome. ${ }^{94}$ The word derives from "officium, the sense of duty belonging to a person with recognized responsibilities."95 This understanding was reflected in English and early American law, which defined "office" as "a duty. Although in general an office was a moral duty, in government it was the specialized office or duty of a particular government employee or servant." 96

88. US Const Art I, s 9, cl 8; see also ibid at Art I, s 10, cl 1 (similarly forbidding individual states to do so).

89. E.g., Yaniv Roznai, "Unconstitutional Constitutional Amendments-The Migration and Success of a Constitutional Idea" (2013) 61 Am J Comp L 657 at 714 (contemporary constitutions include universal principles "such as the democratic nature of the state, human dignity of the individual, and the rule of law").

90. E.g., David A Strauss, "Common Law Constitutional Interpretation" (1996) 63 U Chicago L Rev 877.

91. Steve Sheppard, I Do Solemnly Swear: The Moral Obligations of Legal Officials (Cambridge University Press, 2009) at 10 [Sheppard].

92. Ibid at 20 .

93. Ibid at $20,21$.

94. E.g., JE Lendon, Empire of Honour: The Art of Government in the Roman World (Clarendon Press, 1997).

95. Joshua Getzler, “'As If:' Accountability and Counterfactual Trust” (2011) 91 BU L Rev 973 at 981 .

96. Philip Hamburger, "Judicial Office" (2011) 6 JL Phil \& Culture 53 at 54 [Hamburger]. 
Although the modern conception of office came to treat it as a particular, typically governmental position, and an officer as whichever person happens to fill that office at the moment, the evolving understanding of office involved "both a duty and the position of a particular officer." 97 Coke wrote that "Offices are duties, so called, to put the Officer in minde of his duty." 98 And Richard Hutton, a judge of the Court of Common Pleas, asked: "What are the highest places, but obligations of the greatest dewties?"99

Different offices and officers have different duties. Judges have a set of judicial duties that define their office. The point deserves emphasis. Modern discussions of judging often speak in terms of judicial authority or power. They assume the existence of ethical or other duties attaching to the office of the judge but give them less attention. A focus on the primacy of duty in defining the judicial office and its constraints encourages us to think differently about the relationship of individual judges to the judicial role and its obligations. ${ }^{100}$

Drawing on English legal history, Philip Hamburger argues that the "office" of judges is an "office or duty of judgment" paired with "a duty to decide in accord with the law of the land." "The office of judgment consists of the duty to exercise "intellect," not will: "to discern the law and how it applie[s] in particular cases - this exercise of understanding being his judgment." 102 It might be impossible for judges to act with perfect dispassion or to separate completely the exercise of intellect in their judicial capacity from their own conscience and other influences. But "the reality that they would never fully rise to their ideal of judicial office [is] no excuse for failing to try."103

The "duty to decide in accord with the law of the land" means the judge should interpret and apply existing law, and resist departing from it "for the sake of higher law, including higher law ideals of right or justice." 104 Although judges should not depart from the law, neither should they hesitate to apply it, even if that means declaring an act of Parliament inconsistent with the law. They are obliged to engage in "an unfaltering exercise of judgment in accord with the law of the land," and "neither to hold back from it out of prudence nor to go beyond it for the sake of justice." 105 Finally, "they [are] expected to try their best to exercise discretion only in the sense of discerning or judging the law and what it require[s]," not "in the sense of will or choice."106

\footnotetext{
97. Philip Hamburger, Law and Judicial Duty (Harvard University Press, 2008) at 104 [Hamburger, Law and Judicial Duty].

98. Ibid (quoting Coke, Institutes, 3:185).

99. Ibid (quoting Richard Hutton, The Diary of Richard Hutton 1614-1639, edited by WR Prest (Selden Society, 1991) at 122).

100. E.g., ibid at 1-2, 9-14.

101. Hamburger, supra note 96 at 54 .

102. Ibid at 55 .

103. Ibid.

104. Ibid at 55-56.

105. Ibid at 57.

106. Ibid at 63.
} 


\section{The Oath}

To become a judge, one must take an oath. ${ }^{107}$ English judges were required to go through a ceremony reminding them of their duties as judges before taking the judicial oath. ${ }^{108}$ Similarly, the United States Constitution "twice [sees] fit to write in requirements of oath-taking by government officials." 109 The oath is thus a prerequisite for entry into and performance of office, including judicial office. It is "“an insufficient but nonredundant part of an unnecessary but sufficient condition' - an INUS condition"110_for judicial and other governmental offices: "a part of a constellation of conditions that are jointly sufficient for becoming a judge." 111

But its purpose is more than technical. The solemnizing nature of the oath is essential in turning a citizen into an officer. The judicial oath "transform [s] one into a judge." 112 It constitutes "a bond between the oath-taker and an abstract notion of the institution served or the law itself." 113 The oath, we will see, is one of a troika of institutions - office, honour, and oath - that connect the individual to the office, and the moral duties of the individual to the moral and legal duties of the officer. In the process, these institutions connect the individual judge to the "impersonal" rule of law.

To appreciate this, we must examine the nature of the oath, its connection to office and honour, and continuing justifications for the oath. ${ }^{114}$ We can identify several essential components of the oaths that are relevant here: oaths for officeholders and other public actors. These oaths are personal, promissory, powerful, public, and political.

Personal. Oaths are not taken corporately: an appeals court does not swear a collective oath. Even new citizens, military recruits, or bar members taking the

107. E.g., Sheppard, supra note 91 at 105; Hamburger, Law and Judicial Duty, supra note 97 at 106-07. See also Williamson c Mercier, [2004] RJQ 1933 (CS) (retired judges appointed for a brief term of judicial activity required to re-take judicial oath before they could act in a judicial capacity).

108. Hamburger, Law and Judicial Duty, supra note 97 at 107.

109. Sanford Levinson, Constitutional Faith (Princeton University Press, 1988) at 91 [Levinson]. See U.S. Const, art II, $\S 1$, c. 8 . (prescribing oath taken by the president "[b]efore he enter on the Execution of his Office"); ibid, art VI, cl 3 (requiring state and federal officials to take oath "to support this Constitution").

110. Jeffrey Brand-Ballard, Limits of Legality: The Ethics of Lawless Judging (Oxford University Press, 2010) at 155 (quoting JL Mackie, "Clauses and Conditions" (1965) 2 Am Phil Q 245) [Brand-Ballard].

111. Ibid.

112. Ibid; see ibid at 155 ("Taking the oath is a performative speech act that, given the right background conditions, converts one into a judge.") [emphasis added]; Daniel P Sulmasy, "What is an Oath and Why Should a Physician Swear One?" (1999) 20 Theoretical Med \& Bioethics 329 at 332 ("[An oath] is not merely a commitment to do something or not to do something. It is a commitment to be a particular sort of someone.") [Sulmasy].

113. Sheppard, supra note 91 at 107.

114. For present purposes, the term oath includes sworn affirmations. The religious or potentially religious aspects of oaths are discussed below. It is, of course, useful to remember the religious roots of the oath. E.g., Eric G Andersen, "Three Degrees of Promising" (2003) 2003 BYU L Rev 829 at 846-50 [Anderson]. Nonetheless, in the argument that follows, the religious element of the oath is less important than its solemnity and its function as a call to witness, including by one's peer group. Affirmations meet these criteria. 
oath in a mass ceremony do not swear or affirm as a group. Each person swears or affirms individually. The oath "is a personal, solemn undertaking."115 It is designed both to impress upon each individual oath-taker the seriousness of her commitment to an office and to assure the public that the individual oath-taker is trustworthy. Hamburger puts the point eloquently:

[A] judge had a lonely task, for by virtue of his oath, the obligation of judicial office rested on him as an individual. Not the judiciary, nor even a particular court, took the oath of office .... [J]udges thus had a personal obligation to God to serve [properly] in their office, and this was true whether they acted as part of their court in giving judgment or more individually-for example, where giving advisory opinions. With regard to all such matters, each judge was bound to judge the law for himself in his own conscience. ${ }^{116}$

Promissory. Although oaths are technically distinct from promises, ${ }^{117}$ the kind of oath discussed here is "a very special kind of promise." 118 A judicial oath is "a commitment to faithfully perform the duties of public office." 119 The promissory nature of the judicial oath is an essential element of the rule of law. ${ }^{120}$

Powerful. Oaths are "performative utterance[s] with [great] moral weight."121 Speaking the words of the judicial oath makes one a judge, subject to all the duties of judicial office. Moreover, it is constitutive not only of one's duties and future actions, but, in an important sense, of one's self. It is "a commitment to be a particular sort of someone." 122

The oath thus involves greater stakes than the typical promise, which is simply a commitment, generally defeasible, to do something reasonably mundane, like fulfill a contract. At worst, one might have to pay damages for non-performance and perhaps suffer harm to one's relationships or reputation. The oath "risks the honor and person of the one who swears in a much deeper way." 123 By yoking one's official status to a transformative personal commitment, the judicial oath puts more than outward reputation at risk. Because one commits personally to follow the duties of a judge faithfully, and given the link between internal honour and selfhood, a failure to meet that commitment puts one's very self at stake.

115. Steve Sheppard, "What Oaths Meant to the Framers' Generation: A Preliminary Sketch" (2009) 273 Cardozo L Rev de novo 276 at 276 [emphasis added].

116. Hamburger, Law and Judicial Duty, supra note 97 at 109.

117. Sulmasy, supra note 112 at 330-31; Andersen, supra note 114 at 839.

118. Sulmasy, supra note 112 at 331.

119. Andersen, supra note 114 at 839.

120. CfRichard M Re, "Promising the Constitution" (2016) 110 Nw U L Rev 299 (arguing that the promissory nature of the Oath Clause in the United States Constitution gives rise to a specific set of interpretive duties for judges interpreting the Constitution) [Re]

121. Sulmasy, supra note 112 at 331 ; Brand-Ballard, supra note 110 at 155 .

122. Sulmasy, supra note 112 at 332 .

123. Ibid at 332; see also Giorgio Agamben, The Sacrament of Language: An Archaeology of the Oath, translated by Adam Kotsko (Stanford University Press, 2011) at 21 ("[A]11 of man, in life and death, can be called to account in and by [the oath].") [Agamben]. 
The public nature of the oath is an important aspect of this commitment. "A promise may be public or private, but an oath is necessarily public. Oaths are pronounced for all to hear."124 As a "formal commitment in which the oath-taker intends other people to take reliance" on the promises made, the oath requires, and is deeply tied to, its public performance. ${ }^{125}$ Judicial oaths have long been embedded in a set of solemn public ceremonies. ${ }^{126}$ Long after other ceremonies have lost the power to move others, the oath ceremony remains a solemn one treated with great seriousness. ${ }^{127}$

The public nature of the oath-taking ceremony for public officials raises questions about the precise nature of the "public" that is involved. Discussions of oaths often focus on their religious aspects; i.e., on the fact that God is invoked in the traditional oath. Critics of the oath have long suggested that it is absurd to suggest that "man is able to control the power of God by deciding when that power [to punish for dishonesty] is used."128 This mistakes the nature of the religious invocation in the oath. Its purpose is "not to call the attention of God to man; but the attention of man to God-not to call on Him to punish the wrongdoer, but on man to remember that He will." 129 In that sense, God is one of the witnesses to the oath-taking ceremony. At least for the genuinely religious oathtaker, this again raises the stakes of the oath, "implicat[ing] the deepest aspects of the self, which is understood only in the relationship of the self to God." 130

Crucially, however, the oath is taken not only "to God, or only to oneself, or to one's own moral code; it is ... made to other individuals." 131 It creates "promissory duties to the general public, to [one's] fellow judges, and to other public officials." "132 For Hamburger, the public nature of the oath ceremony, and the fact that the "public" involved often included one's fellow judges, was a crucial element in both recognizing human frailty and bolstering the judge's commitment and courage:

These ceremonies are suggestive about how social pressures were brought to bear in support of the obligation owed to God. Men cannot live on ideals alone, and as evident from the ceremonies, the judges in doing their duty could draw courage from the expectations of the bench and bar, not to mention the broader populace. ${ }^{133}$

124. Sulmasy, supra note 112 at 332.

125. Sheppard, supra note 91 at 107.

126. Hamburger, Law and Judicial Duty, supra note 97 at 106-08.

127. See Jeffrey Toobin, The Oath: The Obama White House and the Supreme Court (Doubleday, 2012) at 1-15 (discussing how seriously the slight error in the language of the presidential oath taken by President Obama in 2009 was taken).

128. Andersen, supra note 114 at 848 (discussing Jeremy Bentham's objections to the oath).

129. Simon Greenleaf, A Treatise on the Law of Evidence, 16th ed (Boston, Little, Brown and Company, 1920) § 364(a) at 504 (quoted in Andersen, supra note 114 at $848 \mathrm{n} \mathrm{64);}$ Sheppard, supra note 91 at 106 ("The oath called upon god to observe the oath-taker's conduct").

130. Andersen, supra note 114 at 849 ; John T Noonan, Jr, "Judicial Impartiality and the Judiciary Act of 1789" (1989) 14 Nova L Rev 123 at 124-25 [Noonan].

131. Sheppard, supra note 91 at 107; Brand-Ballard, supra note 110 at 154 .

132. Brand-Ballard, ibid at 144.

133. Hamburger, Law and Judicial Duty, supra note 97 at 108. 
Thus, one crucial aspect of the public nature of the judicial oath is that it occurs in the presence of one's judicial peers, or honour group. Because one's deepest motivations for decision-making are inaccessible to others, and because office involves the exercise of discretion, it is difficult to guarantee that a judge will act not only within the formal requirements of the law, but faithfully to the law and to judicial duty. With the oath ceremony, the judge enters into judicial office with a powerful reminder that she is being watched and judged for her faithful performance of her duties. Her reputation is put at stake from the very first moment in office. She is literally put on her honour: given notice that her peers will pay attention to what she does and expect her to perform her duties honourably. Insofar as she internalizes that sense of honour, she will (or should) care that even those aspects of the job that are invisible, such as the internal motives for a decision that can be dressed up in appropriate legal language, are performed properly.

Finally, the oath is political, in a fundamental and constitutive sense, as well as personal. It represents "a bond between the oath-taker and an abstract notion of the institution served or the law itself." 134 It signifies and embodies the importance of offices as "trusts' to be executed by public officials," and which are " "bound on the conscience"" of the oath-taker as a fiduciary duty. ${ }^{135}$

This idea is richly explored in Giorgio Agamben's "archaeology" of the oath. ${ }^{136}$ For Agamben, "[t]he essential function of the oath in the political constitution" is its capacity to preserve and stabilize the law and other elements of our political order. ${ }^{137}$ Its personal and political aspects are connected by the relationship between humanity, language, and politics. He writes, "[t]he enigmatic institution, both juridical and religious, that we designate with the term oath can only be made intelligible if it is situated within a perspective in which it calls into question the very nature of man as a speaking being and a political animal."138 The oath is ultimately about the desire to "conform human language" to the "divine model," in which language is truth and carries credibility and reliability. ${ }^{139}$ The oath thus seeks to establish trust in human —and, necessarily, political—relations.

Faithfulness in language and in promises, which is the "foundation of law," ultimately concerns "the correspondence between language and actions." Given the "ethical relationship ... between the speaker and his language," and inasmuch as politics and political relationships depend on a correspondence between language and action, the oath thus "express[es] the demand, decisive

134. Sheppard, supra note 91 at 107.

135. Levinson, supra note 109 at 93 (quoting James Madison). A recent spate of public law literature has emphasized the fiduciary nature of public officials in constitutional systems and sought to draw implications for judging and other official actions. E.g., Evan J Criddle, Evan Fox-Decent, Andrew S Gold, Sung Hui Kim, Paul B Miller, eds, Fiduciary Government (Cambridge University Press, 2019).

136. Agamben, supra note 123 at 1,2 .

137. Ibid at 2,3 .

138. Ibid at 11 .

139. Ibid at 21 .

140. Ibid. 
in every sense for the speaking animal, to put its nature at stake in language and to bind together in an ethical and political connection words, things, and actions." "141

On this view, we are mistaken to view judicial or other oaths as quaint relics or "perfunctory ritual[s]."142 Of course they can be treated that way, just as we can treat offices as being about sheer power and not about duties and limitations. In doing so, however, we lose sight of what is implicated, both personally and politically, in the concepts of oath and office. Both are essential, intertwined, and deeply connected to the individual who commits to acting faithfully according to the duties of office. The oath connects the person to the office and connects both to the possibility of a sound and faithful political order, in which promises and performance, language and the reality it purports to describe, are one.

\section{The Troika: Office, Oath, and Honour, and Their Connection to the Rule of Law}

It remains to tie together office, oath, and honour, and to show how this "troika" is vital to the rule of law, despite the common tendency to treat the rule of law as wholly impersonal. With much of the groundwork already laid, we can move fairly swiftly here.

The rule of law is underpinned by office. This is true of any legal or political office, but it is especially important for judicial office. The ancient roots and basic concepts of judicial office remain relevant today. Judicial office is not primarily a matter of power. Although courts do exercise significant power, it is a mistake to think of judicial office solely in those terms. It is rather a matter of duty and constraint. Judicial power is not a thing in itself, but a product of the proper exercise of judicial office. That exercise is one of judicial duty: of the obligation to decide as a judge, within one's office and according to the law of the land.

As with all offices, judicial office involves discretion. Discretion distinguishes offices in general from other roles within the legal, political, and bureaucratic system. Someone whose sole job is to stamp a document "ACCEPTED" or "DENIED" according to mechanical specifications may have an enormous influence on the lives of the individuals whose documents she stamps. But hers is a job, not an office. That job is ministerial: it involves no exercise of judgment or discretion. Those functions are performed by someone higher up, occupying an office-as judge or political official—whose duty involves exercising judgment in shaping the criteria to be applied by government employees. If the job of sorting and stamping according to the criteria laid down by the officer could be performed by a computer, nothing crucial would be lost. But the decisions involved in setting the criteria necessarily involve the exercise of discretion by someone occupying an office.

141. Ibid at 69.

142. Noonan, supra note 130 at 124 . 
Moreover, it is an essential function of office, properly performed, that the discretion involved is official discretion. It is not absolute or free-ranging. Judicial discretion is channeled and constrained discretion, which must be exercised consistently with one's duty to decide in accordance with the law of the land. It is not personal discretion, and the sorts of factors that may reasonably influence one's personal discretion are excluded from consideration here. ${ }^{143}$

What constitute legitimate or excluded bases for judicial discretion is, of course, a contested question. ${ }^{144}$ But that is a question about the relevant functions and factors for the exercise of judicial office. It does not alter the general understanding that discretion within judicial office excludes some reasons and bases for decisions, even if they would be permitted when exercising personal discretion. This is what we mean when we speak of the rule of law as being "impersonal." 145 It is impersonal in that it is official-and the exercise of one's office involves faithfully following the duties and constraints of that office.

Judges, of course, are human-subject to the same influences, temptations, and errors as everyone else. What can motivate them to be "impersonal" in the relevant sense - to act only within the bounds of and for reasons consistent with their office? What can lash them to the mast of their office, seal their ears with wax to deafen them to irrelevant considerations, and hold them to their duties despite human frailty? ${ }^{146}$

The oath is essential in answering that question. Its aim is to put the oathtaker's "nature at stake in language and to bind together in an ethical and political connection words, things, and actions." "147 It is a "personal obligation" to act impersonally according to the terms of one's oath and one's judicial office. ${ }^{148}$ The oath imposes upon the person who takes it a profound obligation to act within her office. Although the oath may offer some specifications of that office and of one's duty as an official, it is not merely a set of instructions. Rather, it is a general, solemn promise to act according to one's judicial office and in accordance with judicial duty. ${ }^{149}$

143. See Brand-Ballard, supra note 110 at 144 (judicial fidelity involves exclusionary reasons that forbid judges to deviate from the required decision in "required-result" cases or from the official criteria for decision-making in "optimal-but-not-required" cases").

144. A common example is the question whether empathy is a relevant and legitimate factor in judging. E.g., Thomas B Colby, "In Defense of Judicial Empathy" (2012) 96 Minn L Rev 1944; Susan A Bandes, "Empathetic Judging and the Rule of Law" (2009) Cardozo L Rev de novo 133.

145. E.g., Randy J Kozel, Settled Versus Right: A Theory of Precedent (Cambridge University Press, 2017) at 18 (emphasizing the importance of stare decisis in providing "an abiding sense of stability and impersonality" in law).

146. See Jon Elster, Ulysses and the Sirens: Studies in Rationality and Irrationality (Cambridge University Press, 1979) at 37-47 (using Ulysses' tale to illustrate pre-commitment strategies).

147. Agamben, supra note 123 at 69.

148. Hamburger, Law and Judicial Duty, supra note 97 at 109 [emphasis added].

149. Richard Re has argued that American judicial oaths may require particular interpretive methods and substantive positions. E.g., Re, supra note 120 (judicial oath binds American judges to certain interpretive methods and positions in constitutional cases); Richard M Re, "Equal Right to the Poor" (2017) 84 U Chicago L Rev 1149 at 1152-53 (the judicial oath for American federal judges, which commits them to "do equal right to the poor and to the rich," supplies a basis for an "equal right" principle that may "call[ ] for some measure of 
That promise can lead to momentous results. In the United States, the signature example is Chief Justice Marshall's opinion in Marbury v. Madison, ${ }^{150}$ which, rightly or wrongly, ${ }^{151}$ has been treated as establishing the basis for constitutional judicial review. In arguing for the existence and necessity of judicial review, Marshall invoked both the general constitutional oath taken by all officeholders in the United States and the oath prescribed by Congress for federal judges:

[I]t is apparent that the framers of the constitution contemplated that instrument, as a rule for the government of courts, as well as of the legislature.

Why otherwise does it direct the judges to take an oath to support it? This oath certainly applies, in an especial manner, to their conduct in their official character. How immoral to impose it on them, if they were to be used as the instruments, and the knowing instruments, for violating what they swear to support?

The oath of office, too, imposed by the legislature, is completely demonstrative of the legislative opinion on this subject. It is in these words, 'I do solemnly swear that I will administer justice without respect to persons, and do equal right to the poor and to the rich; and that I will faithfully and impartially discharge all the duties incumbent on me as according to the best of my abilities and understanding, agreeably to the constitution, and laws of the United States.'

Why does a judge swear to discharge his duties agreeably to the constitution of the United States, if that constitution forms no rule for his government? If it is closed upon him, and cannot be inspected by him?

If such be the real state of things, this is worse than solemn mockery. To prescribe, or take this oath, becomes equally a crime. ${ }^{152}$

Powerful though this exercise of judicial duty may be, Marshall still describes it as a duty, not a power. The oath both compels the exercise of that duty and limits it to the constraints of one's office as a judge. As important as its role in monumental cases, then, is the limiting function of the judicial oath in seemingly mundane cases. It calls upon the judge to do what the law and her oath require, whether it involves displaying what looks to the world like greatness or, with equal conviction and rigor, deciding in a way that deprives the judge of glory

substantive economic equality" in judicial decision-making). I am much less inclined to think that oaths issue in such specific substantive implications, but Re's work is valuable and much worth reading.

150. 5 U.S. (1 Cranch) 137 (1803).

151. E.g., Hamburger, Law and Judicial Duty, supra note 97 at 2-12. Criticisms of Marshall's oath-based argument include the classic rejoinder of Justice Gibson of the Pennsylvania Supreme Court in Eakin v Raub, 12 Serg \& Rawle 330, 352 (Pa 1825) (Gibson, J, dissenting). Gibson rejects Marshall's claims for the oath as the basis for judicial review-but agrees that the oath is an essential guarantor of the character of the office-holder. Ibid ("The oath to support the constitution is not peculiar to the judges, but is taken indiscriminately by every officer of the government, and is designed rather as a test of the political principles of the man, than to bind the officer in the discharge of his duty.").

152. Marbury, supra note 6 at 180 . 
and the spotlight. If the faithful exercise of judicial office sometimes exemplifies the maxim "Let justice be done though the heavens fall," 153 it is just as likely to result in the judge saying, in effect, "Let justice be done though a sympathetic party suffers." 154 In either case, what is called for is fidelity to judicial duty and the judicial office-whether it leads to a monumental or a mundane result. Either outcome may show judicial duty and even judicial greatness. Both stem from the same vow.

Again, though, judges are human. Even if the oath invokes one's highest ideals and commitments as a lawyer, judge, and citizen, some spring is needed to encourage the judge to hold fast to her oath with energy, courage, loyalty, and resolve. Something must encourage "robust political agency" in an official, whether that agency involves greatness in dutiful action or greatness in dutiful restraint. $^{155}$

Unsurprisingly, that "something" is-or can be-honour, properly understood. Recall that honour is Janus-faced, both inward- and outward-looking. It involves the desire to be thought well of and the desire to act in a way that warrants being thought well of, whether one is being watched or not. And it involves not the quest for celebrity or fame, but "'peer honor,' which governs relations among equals" within an honor group. ${ }^{156}$ Even as society has become more egalitarian and dignity-oriented, honour still matters within particular peer groups. One honours a peer not simply for possessing equal human dignity, but for exemplifying the virtues of the office-holder in a constitutional democracy. That sort of greatness merits high esteem - and its absence should be a source of shame, leading to the withholding of honour by one's peers.

All this is relevant to contemporary office-holding and especially to judicial office-holders. Their work mostly goes unnoticed by the general public. They are watched most closely by members of a small group consisting of their fellow judges and other lawyers. Unlike many other office-holders, they do not much depend on public approval. But, for various reasons, judges may care deeply about the esteem of their colleagues in the judiciary and in the legal profession. That peer group may recognize and applaud those judges who show not only legal acumen, but judicial virtue.

153. See Rex $v$ Wilkes (1770) 98 ER 327 (Lord Mansfield, CJ).

154. E.g., United States $v$ Locke (1985) 471 US 84 (adhering to the textual rigidities of a statutory filing deadline that used the language "prior to December 31 " instead of reading it as requiring filing "on or before December 31," with the result of extinguishing a claim filed on the 31st). Locke's author, Justice Thurgood Marshall, was one of the foremost architects of civil rights litigation in modern American law in the 20th century. As a lawyer and a judge, he gave the Supreme Court multiple occasions for judicial "greatness." He nevertheless insisted here that "the fact that Congress might have acted with greater clarity or foresight does not give courts a carte blanche to redraft statutes in an effort to achieve that which Congress is perceived to have failed to do." Ibid at 95. But see Lawrence M Solan, "Opportunistic Textualism" (2010) 158 U Pa L Rev 225 at 233 (noting that the opinion left room for other possible remedies).

155. Krause, supra note 10 at 65 .

156. Appiah, supra note 17 at 14 . 
Judicial virtue may include not only general qualities that any person might applaud, such as kindness and fairness, but specifically judicial virtues whose traits may be more easily noticed and acknowledged by the judge's professional peers. These virtues include boldness, courage, and fortitude. But they also include restraint: the capacity to faithfully apply the law even when, as the peer group may recognize, one faces temptations to depart from the duties of one's oath and office. Particular cases may tempt judges to apply excluded reasons, such as individual sympathy or a desire for a specific result. They may involve interest groups, sympathetic or powerful or both, who urge a particular result in a case and will publicly criticize a judge who rules to the contrary. Or judges may be tempted to avoid displeasing the ruling regime or powerful members of the bar, and thus harming their chances for advancement.

Even in a non-ideal world, we have reason to hope that a judge's peers will honour the individual who does her duty despite these pressures. And even in a non-ideal world, we have reason to think that a judge will not only care about this esteem, but internalize the values that the peer group honours when it is acting at its best. This judge will show energy, agency, integrity, courage, and an ability to faithfully carry out her judicial office-whether the result is momentous and likely to be widely noticed, or mundane and likely to escape the attention even of her peers. She will act according to proper and not excluded reasons in exercising her office, even where, as is surely often the case, the reasons for her decision will be opaque, if not invisible.

\section{Conclusion: The Troika and the Personal Springs of the "Impersonal" Rule of Law}

The Coxford Lecture aims to "address important public law questions in order to promote and advance the rule of law." 157 The question posed by this article has been how to "promote and advance" the impersonality that is closely and enduringly associated with the rule of law. What motivational springs, incentives, and constraints can make law and its administration "impersonal" in a deeply human world? Simply asserting that judges are impersonal is surely an inadequate answer. Equally simplistic assertions that impersonality is a "myth," 158 law is power, and so on are also inadequate. Such statements move quickly from insight to cliché. Moreover, even those who assert that absolute impersonality is unattainable in the law rarely suggest that judges should have free rein to decide questions on any "personal" basis they choose.

We can do better than either answer. We have at our disposal centuries of legal and political theory and practice involving the rule of law and the nature of government. They offer more than either the blunt assertion that impersonality is essential or the blunt assertion that it should be rejected altogether.

157. "Honour, Oaths and the Rule of Law Explored at Coxford Lecture" (2016) Western Law Alumni Magazine at 8.

158. E.g., Harry P Stumpf, American Judicial Politics (Prentice Hall, 1988) at 42. 
One braided strand we can draw from literature and experience champions neither impersonality nor personality as such. It focuses instead on how personality can be made to serve impersonality. Offices are occupied by human beings. But they channel human impulses through role morality and norms, the desire for respect and reputation, and a strong sense of institutional and official duties, constraints, and expectations. Those motivations are encouraged by solemnization, ceremony, and meaningful public promises-through oaths. As Agamben suggests, the ancient nature of the oath is not a sign of antique status, but of its lasting power. It offers a way of understanding human beings as political animals operating through language, for whom there is an "ethical relationship ... between the speaker and his language." 159 The oath underscores for the office-holder the significance of her promise to perform properly her duties in office.

Both office and oath are intertwined with a third concept: honour. Honour is far from obsolete in modern liberal democratic society. To the contrary, precisely because political apathy is a serious risk in modern society and "active citizenship [is] needed for [a] successful political order," it may be more necessary than ever. ${ }^{160}$ Something must provide the motivation and energy that leads individuals within an egalitarian society to take risks and shoulder burdensome tasks. ${ }^{161}$ For those individuals, the desire to be thought of, and think of oneself, as deserving of honour can be a powerful motivation. It can inspire someone to take on a difficult office, and sustain her in carrying out the duties of that office faithfully despite the temptation to depart from its constraints. For specialized peer groups invested with essential public duties, such as lawyers and judges, who monitor each other and accord or withhold honour to their peers, it continues to serve as a powerful value, especially in its internalized form. Taken together, the troika of office, oath, and honour offer a personal motivation to advance and promote the impersonality required by the rule of law.

Even those inclined to agree with this argument may worry that we will honour the wrong things. Even within the law-steeped culture of judges and lawyers, we may value fame and celebrity over a deeper, internalized sense of earned honour. We may value judicial "greatness" only when it takes the form of bold action favoring what we consider socially just results, and not when it involves mundane cases and practices, such as adhering to the law despite one's personal sympathies in a way that draws no headlines but still exemplifies loyalty to the duties and constraints of one's office. Moreover, the legal peer group may function poorly if it lacks consensus about what the judicial office requires, and about what is or isn't honourable judicial behavior. Of all the concerns raised, this last one, I think, and not charges that institutions such as honour or the oath are obsolete, is the most worrisome.

159. Agamben, supra note 123 at 69 .

160. Steven C Skultety, "A Neo-Aristotelian Theory of Political Honor" in Johnson \& Demetriou, supra note 15 at 89, 94; see ibid at 94, 105 (arguing that "liberal democratic societies are shot through with political honor," including the view that judicial and other high offices are an honour).

161. Ibid at 96 (summarizing Krause's arguments sympathetically, while going on to offer some useful concerns and criticisms). 
This worry is a reason to continue rather than abandon this discussion. Perhaps more than we realize, we need to reconstruct, revise, and champion the concept of honour, not to reject it. Similarly, as long as we continue to believe in rule-of-law values, including impersonality, we need to think more deeply about what judicial office and the judicial oath mean - and what they demand of those who occupy those offices and take those oaths. We need, in sum, to think more deeply about concepts that until recently were treated by many liberal thinkers as obsolete at best and harmful at worst-concepts like office, oath, and honour-and their relationship to public law. 